\title{
A new species of Microglanis (Siluriformes: Pseudopimelodidae) from the rio Uruguay drainage, Brazil
}

\author{
Vinicius A. Bertaco and Alexandre R. Cardoso
}

A new pseudopimelodid catfish, Microglanis malabarbai, is described from the rio Ijuí drainage, tributary of the middle rio Uruguay, Rio Grande do Sul, Brazil. The new species is distinguished from all other Microglanis species by the caudal fin color pattern, almost completely black, with a narrow vertical white band across central portions of the caudal-fin rays. Furthermore, it is distinguished from $M$. cottoides and M. eurystoma, both from rio Uruguay drainage, by head length, maxillary barbel length, internareal distance, and number of lateral-line pores, and from $M$. cibelae from the coastal drainages of northern Rio Grande do Sul and southern Santa Catarina states, by head length, maxillary barbel length, and body width. A key is presented for the species of Microglanis occurring in southern Brazil.

Uma nova espécie de pseudopimelodídeo, Microglanis malabarbai, é descrita da bacia do rio Ijuí, tributário do médio rio Uruguai, Brasil. A nova espécie distingue-se das demais espécies de Microglanis pelo colorido da nadadeira caudal, quase completamente preta, com uma pequena faixa vertical branca na sua porção central. Além disso, distingue-se de $M$. cottoides e M. eurystoma, ambas da bacia do rio Uruguai, pelo comprimento da cabeça, comprimento do barbilhão maxilar, distância entre as narinas anteriores e número de poros na linha lateral, e de $M$. cibelae, das drenagens costeiras do norte do Rio Grande do Sul e sul de Santa Catarina, pelo comprimento da cabeça, comprimento do barbilhão maxilar e largura do corpo. É apresentada uma chave para as espécies de Microglanis ocorrentes no sul do Brasil.

Key words: Neotropical, taxonomy, M. eurystoma, M. cibelae, M. cottoides, rio Ijuí, Southern Brazil.

\section{Introduction}

Microglanis is a genus of Neotropical pseudopimelodid catfishes comprising 12 valid species and distributed throughout most of tropical South America on both sides of the Andes (Shibatta, 2003a). The genus is known from Pacific coast drainage in Ecuador, Lake Maracaibo basin (rio Catatumbo), Orinoco basin, coastal drainages of the Guianas, Amazon basin, Río de la Plata basin, and coastal drainages of southern Brazil from the states of Rio de Janeiro to Rio Grande do Sul (Mees, 1974; Le Bail et al., 2000; Shibatta, 2003a).

Recently, Malabarba \& Mahler (1998) reviewed the diversity of Microglanis in the rio Uruguay and coastal drainages of southern Brazil, recognizing three species. Microglanis cottoides (Boulenger, 1891) was considered valid, redescribed, and recorded from the rio Uruguay and rio Jacuí drainages, and two new species were described: M. eurystoma Malabarba \& Mahler, 1998, from the upper rio Uruguay drainage, and M. cibelae Malabarba \& Mahler, 1998, from the coastal drainages of northern Rio Grande do Sul and southern Santa Catarina states.

During inventory field studies conducted by the authors and related to the construction of two hydroelectric dams in the rio Ijuí, an additional undescribed species of Microglanis was discovered in this tributary of the middle rio Uruguay (Fig. 1), Brazil, which is described herein.

\section{Methods and materials}

Measurements were taken as described in Malabarba \& Mahler (1998), including the following additional measurements: caudal peduncle length (measured from the base of the last anal-fin ray to the posterior margin of the hypural fan), dorsal-fin base, adipose-fin base, horizontal orbital diameter, maxillary barbel length, head depth (measured at a vertical immediately before pectoral fin spines), and

Laboratório de Ictiologia, Museu de Ciências e Tecnologia, Pontifícia Universidade Católica do Rio Grande do Sul, Av. Ipiranga 6681, 90619-900 Porto Alegre, RS, Brazil. 
internareal distance (measured between the bases of each nostril flap). Vertebrae, gill-rakers, branchiostegal rays, and procurrent caudal-fin ray counts were taken from cleared and stained specimens (c\&s) prepared according to the method of Taylor \& Van Dyke (1985). Vertebral counts include the caudal centrum, but not the fused elements of the Weberian apparatus.

Measurements were taken point to point with an electronic caliper on the left side of specimens when possible. Measurements are expressed as percents of standard length (SL) except subunits of the head, which are recorded as percents of head length (HL). Morphometric distances were explored using Principal Components Analysis (PCA) on the covariance matrix of log-transformed measurements to assess morphometric variation between species. PCA analyses were performed using the software PAST (Ryan et al., 1995). Factor scores were plotted in the SigmaPlot software (Brannan et al., 2000). Specimens examined belong to the following institutions: MCP, Museu de Ciências e Tecnologia, Pontifícia Universidade Católica do Rio Grande do Sul, Porto Alegre; MCZ, Museum of Comparative Zoology, Cambridge; MZUSP, Museu de Zoologia da Universidade de São Paulo, São Paulo; UFRGS, Departamento de Zoologia, Universidade Federal do Rio Grande do Sul, Porto Alegre, and ZMB, Museum fur Naturkunde der Humboldt Universität, Berlin.

The available samples of M. malabarbai were compared to both geographically isolated populations of $M$. cottoides from the rio Uruguay and laguna dos Patos drainages, and to type specimens of M. eurystoma and M. cibelae.

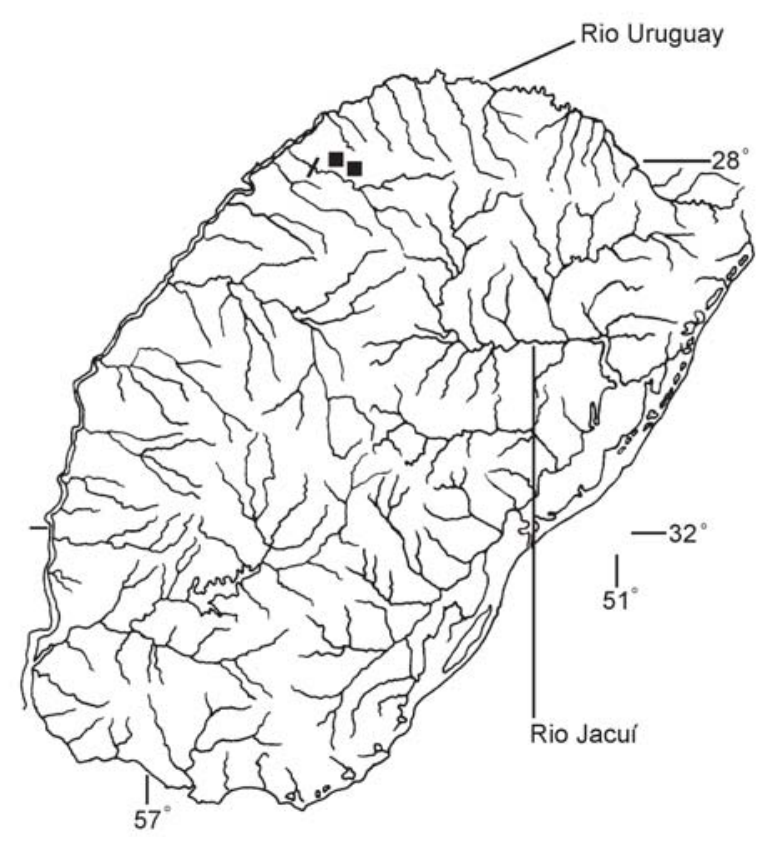

Fig. 1. Rio Grande do Sul, Brazil and Uruguay, with the known distribution of M. malabarbai (squares). Black bar: natural waterfall.

\section{Microglanis malabarbai, new species}

Figs. 1-2

Holotype. MCP 35941 (50.0 mm SL), arroio Albino, tributary of rio Ijuí (rio Uruguay drainage), 2808'10"S 5455'28”W, São Pedro do Butiá, Rio Grande do Sul, Brazil, 12 Jun 2004, A. R. Cardoso \& V. A. Bertaco.

Paratypes. Brazil, Rio Grande do Sul, rio Ijuí drainage: MCP 35339 (1,38.3 mm SL), collected with the holotype. MCP 35761 (5, 31.5-45.7 mm SL), same locality and collectors as holotype, 31 Oct 2004. MCP 35760 (1, 36.4 mm SL), MZUSP 85812 (2, 42.6-46.2 mm SL), arroio Alexandrino, Salvador das Missões, $28^{\circ} 10^{\prime} 25^{\prime}$ 'S 54⒋ '05"'W, 31 Oct 2004, A. R. Cardoso \& V. A. Bertaco. MCP 35762 (1, $43.2 \mathrm{~mm} \mathrm{SL}$ ), arroio Portão, Roque Gonzales, $28^{\circ} 08^{\prime} 21^{\prime \prime}$ 'S 54 58'33'W, 31 Oct 2004, A. R. Cardoso \& V. A. Bertaco.

Diagnosis. Microglanis malabarbai is distinguished from all other species in the genus by having a caudal fin that is almost completely black, with a narrow vertical white band across central portions of the caudal-fin rays. Microglanis malabarbai is further distinguished from $M$. cottoides by the longer head length (29.6-33.5 vs. 25.1-31.2\% SL, Fig. 3), smaller pectoral spine length (17.0-22.5 vs. 20.0-27.5\% SL), smaller maxillary barbel length (63.4-92.4 vs. 91.4-131.6\% HL, Fig. 4), larger internareal distance (24.0-29.1 vs. 19.6-25.2\% HL, Fig. 5), and smaller number of lateral-line pores (6-7 vs. 7-13, Fig. 6). It further differs from $M$. cibelae by longer head length (29.6-33.5 vs. 25.1-28.9\% SL), larger body width (29.3-33.1 vs. 22.3-26.0\% SL), and smaller maxillary barbel length (63.4-92.4 vs. 84.1-144.6\% HL); from M. eurystoma by smaller mouth width (60.5-71.9 vs. 74.1-76.9\% HL), and larger head depth (52.7-61.2 vs. 42.4-48.2\% HL); from M. parahybae by longer head length (29.6-33.5 vs. 23.2-27.6\% SL), higher body depth (17.4-19.8 vs. 12.9-15.6\% SL), and higher caudal peduncle depth (9.4-11.3 vs. 7.6-9.7\% SL); from M. nigripinnis and $M$. ater by color of fins (fins scattered with chromatophores $v s$. all fins black, except caudal fin in M. malabarbai). Microglanis malabarbai also differs from M. ater by having a smaller number anal-fin rays (10-12 vs. 14-15).

Description. Morphometric data for M. malabarbai summarized in Table 1. Body compressed behind dorsal fin. Highest body depth at dorsal-fin origin, largest body width at pectoral-fin base. Head slightly depressed and rounded in dorsal view. Frontal fontanel small, nearly two times eye size. Supraoccipital process short, contacting pre-dorsal nuchal plate. Mouth curved, terminal; mouth gape about same size as head width at opercle. Teeth small and viliform. Premaxillary teeth in rectangular patch about four times wider than long. Dentary teeth patch along whole exposed border of dentary. Gill membranes free, supported by 8 or 9 branchiostegal rays; upper gill rakers of first arch 3 and lower gill rakers 7 ( $2 \mathrm{c} \& \mathrm{~s})$. Barbels thin, flattened in cross section. One maxillary and two mental pairs of barbels. Maxillary barbel short, not reaching base of pectoral-fin spines. Outer mental barbels 
longer than inner, and reaching base of pectoral-fin spines. Anterior nostril near upper lip, at tip of erect tube; posterior nostril near bony orbital margin. Eye closer to mouth than to distal margin of opercle. Lateral line with 6-7 pores (one specimen with 9), reaching vertical line projected over base of last two dorsal-fin rays.

Dorsal fin with spinelet, strong pungent spine, and 5-6 soft branched rays. Spine short, smaller than soft rays, anterior margin smooth and posterior margin serrated in distal portion. Adipose fin of medium size, base longer than length of analfin base. Caudal fin emarginate, lower and upper lobes of equal length with rounded margins; principal caudal-fin rays $15-16$ (mean $=15.5)$. Dorsal procurrent caudal-fin rays 15-16, and ventral procurrent caudal-fin rays 11-12. Anal fin short and rounded; posteriormost rays reaching caudal-fin base; anal-fin rays 10-12 (mean $=10.7), 3-4$ unbranched, 7-8 branched. Pectoral fin with strong spine, 5 soft rays; anterior margin of spine with retrorse hooks on proximal third, antrorse hooks distally; and posterior margin with retrorse hooks along entire length. Posterior cleithral process slender and pointed. Pelvic fin rounded with i, 5 soft rays. Vertebral count $29-30$ in $2 \mathrm{c} \& \mathrm{~s}$ specimens.

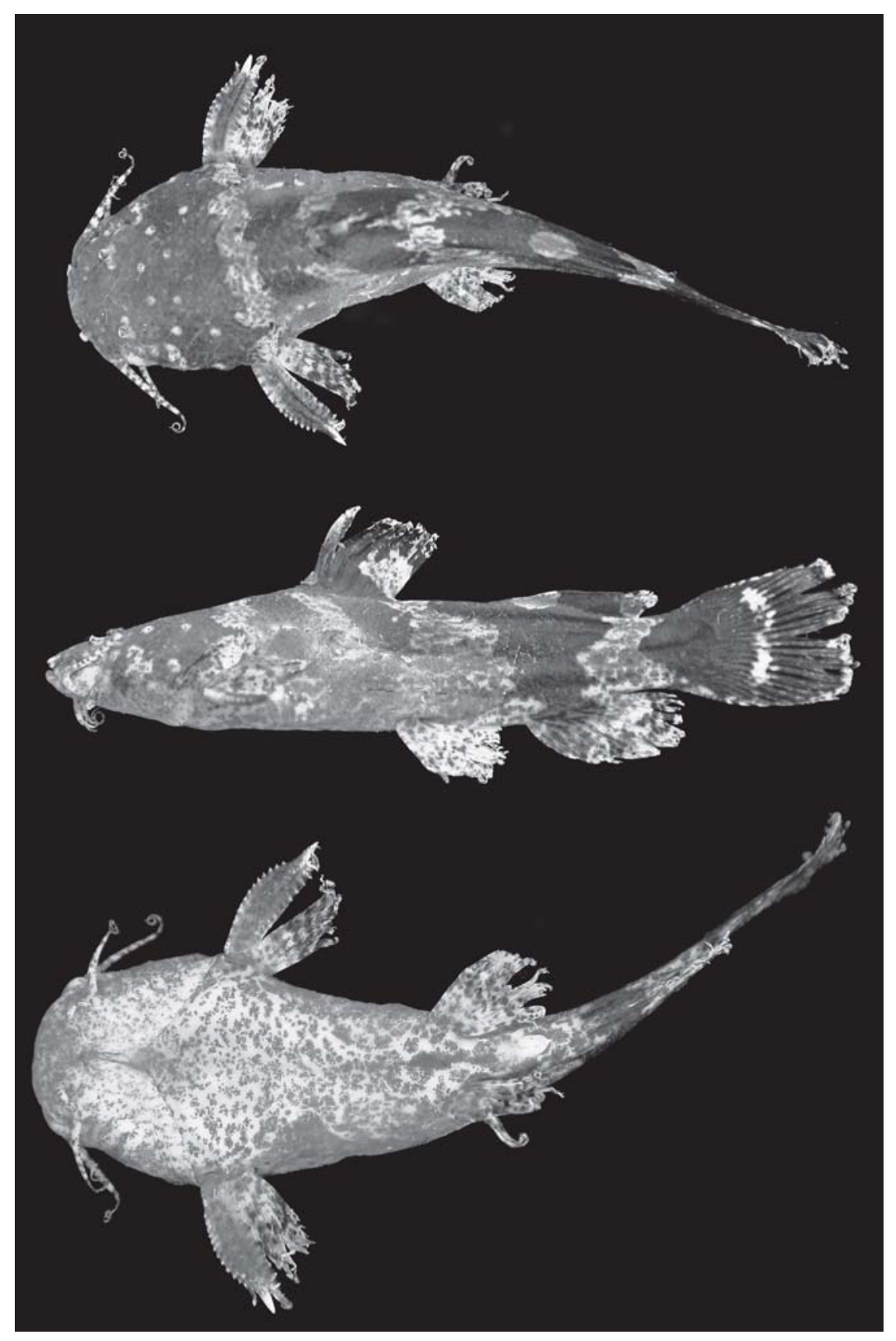

Fig. 2. Microglanis malabarbai, MCP 35941, holotype, $50.0 \mathrm{~mm}$ SL; rio Ijuí, tributary of middle rio Uruguay, Rio Grande do Sul, Brazil. 


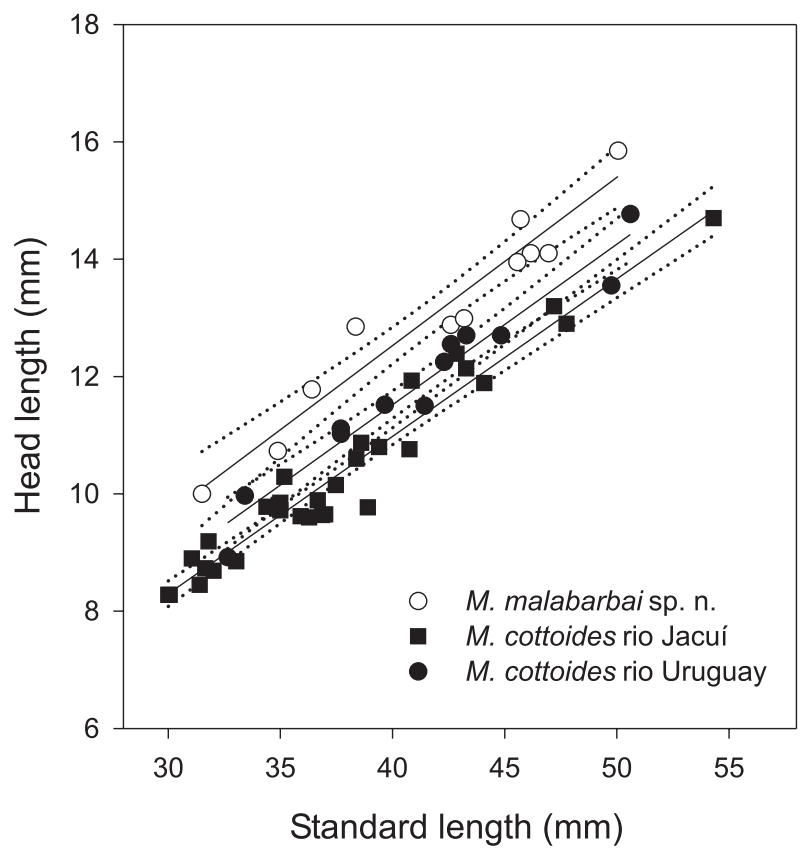

Fig. 3. Regression of head length as function of standard length in M. malabarbai and two populations of $M$. cottoides. Note that $95 \%$ confidence intervals do not overlap with those of compared species indicating statistically significant difference.

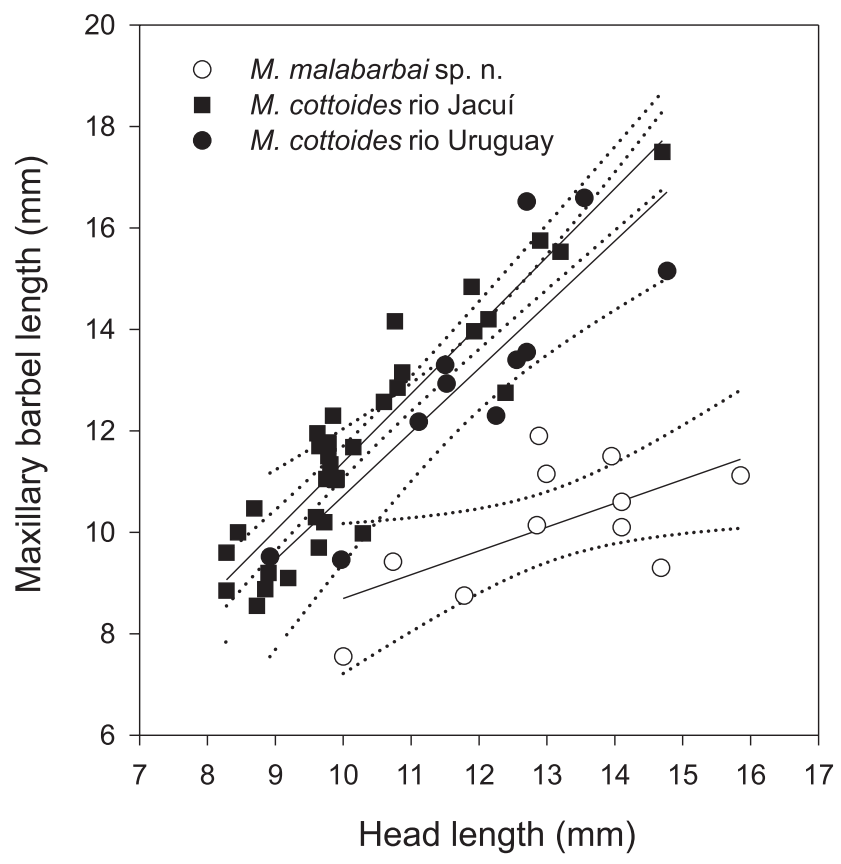

Fig. 4. Regression of maxillary barbel length as function of head length in $M$. malabarbai and two populations of $M$. cottoides. Note that $95 \%$ confidence intervals do not overlap with those of compared species indicating statistically significant difference.
Color in alcohol. Body alternately black and brownish yellow on sides and dorsum; light yellow ventrally. Head black in dorsal view, with transverse white bar connecting opercular openings, small white spot near each posterior nare, two white spots on cheek posteriorly and laterally to eye. Three wide vertical bars on sides of body; widest bar beneath dorsal fin, interrupted internally by light blotch and finishing laterally at lateral line; second bar continuous from base of adipose fin to that of anal-fin; third bar across caudal peduncle with small white spot near dorsal and ventral caudal peduncle profiles. Pectoral and pelvic fins with series of small spots scattered on fin rays. Dorsal fin darkly pigmented, with white wedgeshaped blotch covering part of proximal half of three to four posterior rays; tip of all rays white. Adipose fin crossed in mid-length by black band continuous with second bar on body side. Anal fin crossed by dark black stripe near base, followed by white stripe, spotty black stripe, and white stripe near tip of rays. Caudal fin almost completely black, and some specimens with narrow vertical white band across central portions of caudal-fin rays. Tip of caudal-fin rays white (Fig. 2).

Distribution. Microglanis malabarbai is known only from the rio Ijuí, a tributary of the middle rio Uruguay, Rio Grande do Sul, Brazil (Fig. 1).

Etymology. The specific name honors Luiz Roberto Malabarba for his active contribution to the knowledge of the Neotropical ichthyofauna.

Ecological notes. All specimens of $M$. malabarbai were caught under dead tree branches and leaves in dark water, lentic stretches of shallow streams, with sand and mud on the bottom, and moderate amount of riparian vegetation. The rio Ijuí drainage is surrounded mainly by soybean, wheat, and pasture plantations, with narrow areas of original vegetation on stream margins. Other species collected in same habitat with M. malabarbai are (all lots deposited at MCP): Cichlasoma dimerus, Crenicichla scotti, Heptapterus mustelinus, Hisonotus sp., Rhamdia quelen, and Rineloricaria sp.

\section{Key to species of Microglanis from southern Brazil}

1. Caudal fin almost completely black, with a narrow vertical white band near middle length of caudal-fin rays; maxillary barbel short, not passing pectoral-fin origin

M. malabarbai

(rio Ijuí, tributary of middle rio Uruguay drainage)

1'. Caudal fin with wide white band near middle of caudalfin rays; maxillary barbel long, passing pectoral-fin origin

2. Mouth gape large (67-85\% of HL), head shallow (depth 42$48 \%$ of HL) and squarish in dorsal view in large specimens

M. eurystoma

(upper rio Uruguay drainage)

2'. Mouth gape small (50-70\% of HL), head deep (depth 55- 
$78 \%$ of $\mathrm{HL}$ ) and rounded in dorsal view in large specimens

............................................................................. 3

3. Body narrow (width $22-29 \%$ of SL), head short (25-29\% of SL), and dorsal, pectoral, pelvic, and anal fins with a black distal band M. cibelae (coastal drainages from northern Rio Grande do Sul and Santa Catarina states)

3'. Body wide (width $27-34 \%$ of SL), head long (29-34\% of SL), and dorsal, pectoral, pelvic, and anal fins with scattered chromatophores

M. cottoides

(rio Jacuí and rio Uruguay drainages)

\section{Discussion}

The genus Microglanis was described by Eigenmann (1912: 155) to include small pimelodids with the head as wide as long, the skull covered by skin only; the occipital crest small; frontal fontanel not extending much if any behind the eye, and a minute occipital fontanel sometimes present; eye without a free orbital margin; dorsal and pectoral spines welldeveloped; and premaxillary patches of teeth without backward projecting angles. Furthermore, others authors (Schultz, 1944: 197-198; Gomes, 1946: 7-8; Mees, 1974: 221; 1978: 259; Shibatta, 1998: 111) have evaluated the usefulness of the characters used to distinguish Microglanis from Pseudopimelodus. These genera differ in body size (Pseudopimelodus larger), posterior lateral line poorly developed in Microglanis, and especially in the shape of the premaxillary band of teeth (Mees, 1978). Recently, Shibatta (2003b: 396) presented three possible synapomorphies for Microglanis: (1) premaxillary bands of teeth with lateral margin rounded, (2) mesocoracoid arch filamentous, and (3) body size smaller than $8 \mathrm{~cm}$, as well as two possible synapomorphies for Pseudopimelodus: (1) mesocoracoid arch depressed and triangular, and (2) pectoral-fin spine covered with thick skin. The new species here described has all characters proposed by Eigenmann (1912) as well as the possible derived features found by Shibatta (2003b) and is thus described in the genus Microglanis.

In M. malabarbai the caudal fin is almost completely black, with a narrow vertical white band, a character that is uncommon within the genus. All other Microglanis species have a wide vertical white band in medial caudal-fin portion or the caudal-fin is not pigmented. Malabarba \& Mahler (1998) identified two populations of $M$. cibelae, one from the rio Tramandaí drainage (type locality of the species), and the other from the rio Canoas, tributary of rio Mampituba (northern coastal drainage) with caudal-fin color similar to $M$. malabarbai. Those fishes lack almost completely a vertical white band crossing the caudal-fin, and present an enlarged black area on pelvic and pectoral fins, versus scattered chromatophores observed on $M$. malabarbai. The new species also differs from $M$. cibelae with respect to the head length, body width, and maxillary barbel length (see diagnosis).

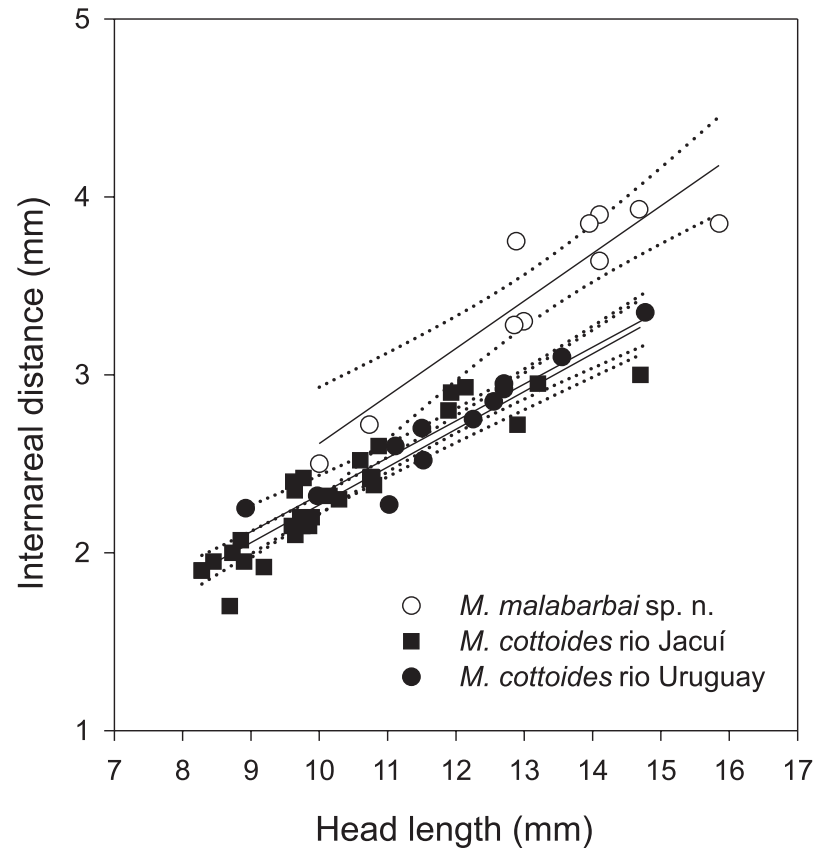

Fig. 5. Regression of internareal distance as function of head length in M. malabarbai and two populations of M. cottoides. Note that $95 \%$ confidence intervals do not overlap with those of compared species indicating statistically significant difference.

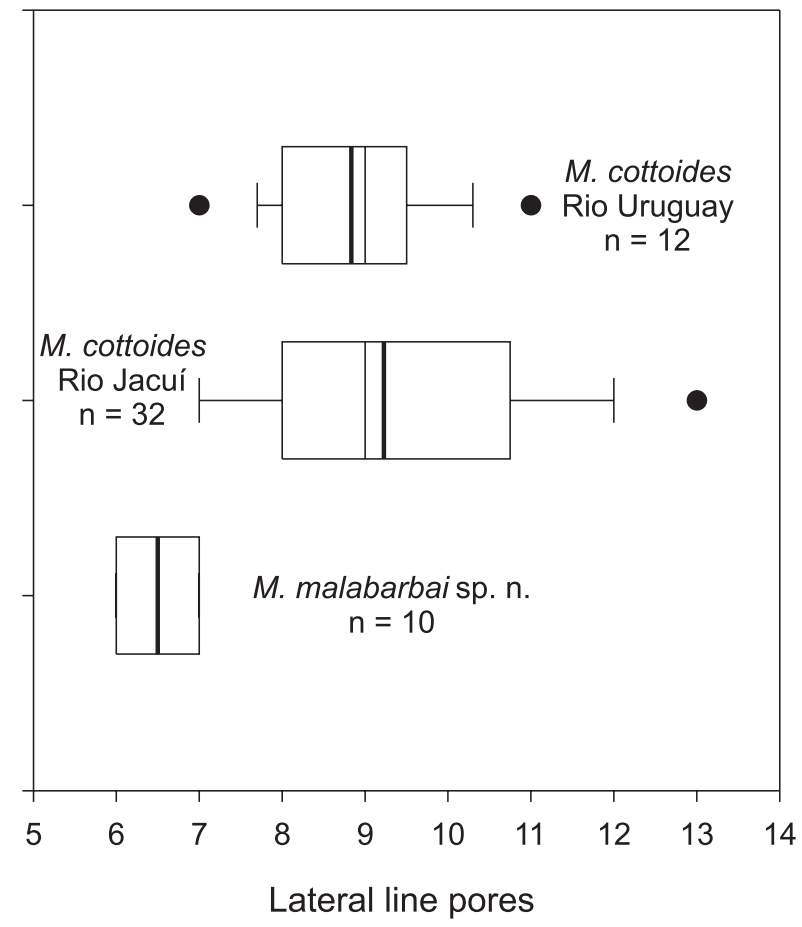

Fig. 6. Tukey box plot number of lateral line pores in $M$. malabarbai and two populations of $M$. cottoides. Mean represented by thick vertical bar, and $25^{\text {th }}$ and $75^{\text {th }}$ percentiles as lateral borders of box plots. 
Table 1. Morphometric data of the holotype $(\mathrm{H})$ and paratypes of Microglanis malabarbai $(\mathrm{n}=11$, including the holotype), and $M$. cottoides from rio Uruguay $(\mathrm{n}=12)$ and rio Jacuí $(\mathrm{n}=33)$ drainages, Rio Grande do Sul, Brazil.

\begin{tabular}{|c|c|c|c|c|c|c|c|}
\hline & \multicolumn{3}{|c|}{ M. malabarbai } & \multicolumn{4}{|c|}{ M. cottoides } \\
\hline & & & & \multicolumn{2}{|c|}{ Rio Uruguay } & \multicolumn{2}{|c|}{ Rio Jacuí } \\
\hline & $\mathrm{H}$ & Range & Mean & Range & Mean & Range & Mean \\
\hline Standard length (mm) & 50.0 & $31.5-50.0$ & 41.9 & $32.7-50.6$ & 41.3 & $30.0-63.7$ & 38.2 \\
\hline \multicolumn{8}{|c|}{ Percents of Standard length } \\
\hline Head length & 31.7 & $29.6-33.5$ & 31.0 & $27.2-29.8$ & 28.8 & $25.1-31.2$ & 27.6 \\
\hline Body width & 30.0 & $29.3-33.1$ & 31.8 & $27.2-32.2$ & 30.1 & $26.7-32.4$ & 29.2 \\
\hline Dorsal spine length & 13.6 & $13.2-16.5$ & 14.9 & $13.7-21.6$ & 16.4 & $13.0-22.4$ & 16.8 \\
\hline Pectoral spine length & 20.4 & $17.0-22.5$ & 19.9 & $20.0-25.4$ & 22.9 & $20.0-27.5$ & 22.8 \\
\hline Predorsal length & 41.7 & $38.4-43.3$ & 40.8 & $37.7-43.4$ & 39.8 & $22.1-41.4$ & 37.7 \\
\hline Prepelvic length & 54.6 & $52.3-57.4$ & 55.0 & $50.2-59.8$ & 54.9 & $50.1-57.9$ & 53.2 \\
\hline Preanal length & 76.7 & $71.4-77.2$ & 74.0 & $71.6-75.8$ & 73.8 & $70.6-75.8$ & 72.9 \\
\hline Caudal peduncle depth & 10.8 & $9.4-11.3$ & 10.4 & $9.3-11.8$ & 10.6 & $9.6-18.5$ & 11.1 \\
\hline Body depth & 18.9 & $17.4-19.8$ & 18.6 & $16.0-21.6$ & 18.5 & $16.2-22.7$ & 19.6 \\
\hline Head width & 21.6 & $19.7-22.3$ & 21.0 & $18.9-21.8$ & 20.2 & $18.9-21.6$ & 20.2 \\
\hline Mouth width & 19.4 & $19.2-22.1$ & 20.5 & $16.5-21.5$ & 18.5 & $15.8-19.3$ & 17.2 \\
\hline Anal-fin base length & 16.0 & $12.1-16.0$ & 14.9 & $12.3-17.6$ & 14.8 & $12.8-16.8$ & 15.0 \\
\hline Caudal peduncle length & 12.5 & $11.1-14.5$ & 12.3 & $11.3-14.5$ & 12.8 & $10.9-15.0$ & 13.0 \\
\hline Maxillary barbel length & 22.2 & $20.4-27.9$ & 24.3 & $26.7-38.2$ & 31.1 & $26.3-36.6$ & 31.5 \\
\hline Dorsal-fin base length & 15.5 & $10.6-15.5$ & 13.6 & $13.7-16.5$ & 14.9 & $12.0-15.9$ & 14.1 \\
\hline Adipose-fin base length & 18.4 & $18.4-23.4$ & 20.9 & $17.5-24.2$ & 20.5 & $17.1-25.8$ & 21.6 \\
\hline \multicolumn{8}{|l|}{ Percents of Head length } \\
\hline Interorbital width & 44.8 & $41.4-46.2$ & 43.8 & $40.4-47.2$ & 44.0 & $39.9-54.0$ & 47.9 \\
\hline Head width & 68.1 & $61.1-72.4$ & 67.8 & $65.4-78.5$ & 70.3 & $67.1-79.2$ & 73.1 \\
\hline Head depth & 53.3 & $52.7-61.2$ & 57.7 & $54.8-64.0$ & 59.4 & $56.2-78.0$ & 62.7 \\
\hline Maxillary barbel length & 70.2 & 63.4-92.4 & 78.6 & $91.4-130.1$ & 108.3 & $97.0-131.6$ & 114.1 \\
\hline Orbital diameter & 10.5 & $10.5-15.1$ & 12.7 & $13.2-16.3$ & 14.5 & $10.6-18.0$ & 14.7 \\
\hline Mouth width & 61.2 & $60.5-71.9$ & 66.4 & $57.2-73.2$ & 64.3 & $54.2-71.7$ & 62.5 \\
\hline Internareal distance & 24.3 & $24.0-29.1$ & 26.1 & $20.6-25.2$ & 22.9 & $19.6-24.9$ & 22.7 \\
\hline
\end{tabular}

Two other Microglanis species occur in the rio Uruguay drainage, M. eurystoma from the upper portions of this drainage, and $M$. cottoides (also occurs in the rio Jacuí drainage). These species do not appear to be syntopic with M. malabarbai. Comparisons of the two geographically isolated populations of $M$. cottoides (rio Uruguay and rio Jacuí drainages) showed no statistically significant differences (Figs. 3-7, Table 1) and support their conspecificity as recognized Malabarba \& Mahler (1998). The results of the principal components analysis (PCA) revealed a complete separation between $M$. malabarbai and the two populations of $M$. cottoides along the second principal component (Fig. 7). PC2 accounts for $6.0 \%$ of the total variance and corresponds primarily to differences in shape (vs. size), contains the main shape. Measurements loading strongly on PC2 are maxillary barbel length (0.57), internareal distance ($0.47)$, pectoral spine length (0.31), and mouth width (-0.28).

The new species described in this paper suggests that the rio Ijuí, tributary of middle rio Uruguay, has a substantial endemic component in its ichthyofauna. An undescribed cichlid fish species of the genus Gymnogeophagus (L. Malabarba and R. Reis, pers. commun.) and a probable new species of Hemipsilichthys (E. Pereira, pers. commun.) are also endemic to the rio Ijuí drainage, suggesting that the rio Ijuí represents a previously unrecognized area of fish endemism. These species occur in tributaries of the rio Ijuí above the natural waterfall located about $50 \mathrm{~km}$ upstream of its confluence with the rio Uruguay. This obstacle may be a

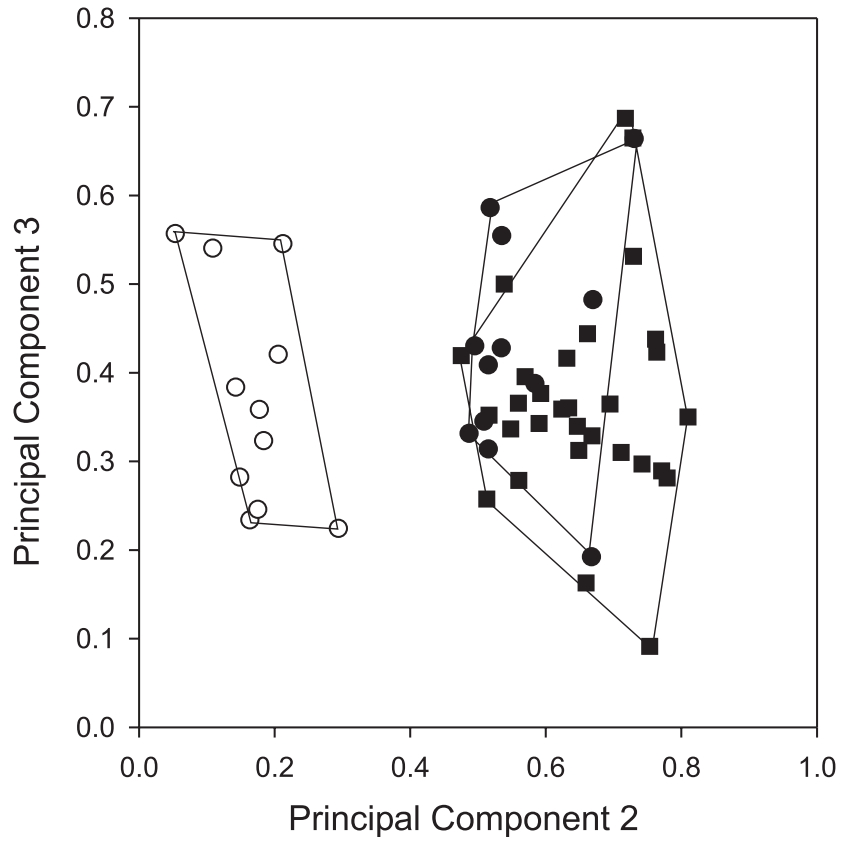

Fig. 7. Scatter plot of principal components analysis on covariance matrix of log-transformed measurements of Microglanis malabarbai (open circles) and two populations of $M$. cottoides from rio Uruguay (black circles) and rio Jacuí (black squares) drainages. 
natural barrier for the dispersal of these species. A hydroelectric dam will be constructed in the rio Ijuí above this natural waterfall, and the stream where the new species was collected will not be inundated.

Comparative material. Microglanis ater: ZMB 20932, holotype; Microglanis cibelae (paratypes): MCP 13636, 1; MCP 14825, 1; MCP 19822, 7. Microglanis cottoides (rio Jacuí drainage): MCP 15491, 3; MCP 17326, 1; MCP 19423, 1; MCP 25033, 1; MCP 25096, 7; MCP 25097, 7; MCP 33603, 1; MCP 33644, 1; MCP 34729, 7; MCP 34730, 6; MCP 34732, 3; UFRGS 2878, 1 c\&s; (rio Uruguay drainage): MCP 10826, 6 of 11; MCP 11061, 1 c\&s; MCP 19819, 4; MCP 19821, 2; MCP 20908, 1; MCP 25196, 36. Microglanis eurystoma: MCP 5717, 1 c\&s; MCP 13405, holotype; MCP 13151, 1 paratype; MCP 11353, 1; MCP 20393, 1. Microglanis parahybae, MCZ 8161, 10 syntypes.

\section{Acknowledgments}

We are grateful for data on syntypes of the M. parahybae furnished by L. Malabarba and by the photography of $M$. ater by Peter Bartsch. The paper benefited from comments and suggestions by R. Reis, L. Malabarba, M. Sabaj, and an anonymous reviewer. Financial support was provided by CNPq - Conselho Nacional de Desenvolvimento Científico e Tecnológico, Brazilian Government Agency for Scientific and Technological Development (Proc. 476821/2003-7; Proc. 464545/00-5).

\section{Literature cited}

Brannan, T., B. Althof, L. J. Jacobs, J. Norby \& S. Rubenstein. 2000. SigmaPlot. Exact Graphics For Exact Science. Version 6.1 for Windows. SPPS. INC.

Eigenmann, C. H. 1912. The freshwater fishes of British Guiana, including a study of the ecological grouping of species and the relation of the fauna of the plateau to that of lowlands. Memoirs of the Carnegie Museum, 5(1): 1-578, pls. 1-103.

Gomes, A. L. 1941. Synopsis of the genera of Pimelodidae catfishes without a free orbital rim. Stanford Ichthyology
Bulletin, 2: 83-88.

Gomes, A. L. 1946. A review of Microglanis, a genus of South American catfishes with notes on related species. Occasional Papers of the Museum of Zoology, 494:1-19.

Le Bail, P. -Y., P. Keith \& P. Planquette. 2000. Atlas des poissons d'eau douce de Guyane. Tome 2, fascicule II: Siluriformes. Patrimoines naturels, 43(2), $307 \mathrm{p}$.

Malabarba, L. R. \& J. K. F. Mahler Jr. 1998. Review of the genus Microglanis in the rio Uruguay and coastal drainages of southern Brazil (Ostariophysi: Pimelodidae). Ichthyology Exploration of Freshwaters, 9(3): 243-254.

Mees, G. F. 1974. The Auchenipteridae and Pimelodidae of Suriname (Pisces, Nematognathi). Zoologische Verhandelingen, 132:1-256.

Mees, G. F. 1978. Two new species of Pimelodidae from NorthWestern South America (Pisces, Nematognathi). Zoologische Mededelingen, 53(23): 253-261.

Ryan, P. D., D. A. T. Harper \& J. S. Whalley. 1995. PALSTAT, Statistics for palaeontologists. Chapman \& Hall, (now Kluwer Academic Publishers).

Schultz, L. P. 1944. The catfishes of Venezuela with descriptions of thirty-eight new forms. Proceedings of the United States National Museum, 94: 173-338.

Shibatta, O. A. 1998. Sistemática e evolução da família Pseudopimelodidae (Ostariophysi, Siluriformes), com a revisão taxonômica do gênero Pseudopimelodus. Unpublished Ph.D. Thesis - Universidade Federal de São Carlos, São Carlos. 353 p.

Shibatta, O. A. 2003a. Family Pseudopimelodidae. Pp. 401405. In: R. E. Reis, S. O. Kullander \& C. J. Ferraris (Eds.). Check List of the Freshwater Fishes of South and Central America. Edipucrs, Porto Alegre, 729 p.

Shibatta, O. A. 2003b. Phylogeny and classification of 'Pimelodidae'. Pp. 385-400. In: G. Arratia, B. G. Kapoor, M. Chardon \& R. Diogo (Eds.). Catifishes, volume 1. Science Publishers, Inc., Enfield, 487 p.

Taylor, W. R., \& G. C. Van Dyke. 1985. Revised procedures for staining and clearing small fishes and other vertebrates for bone and cartilage. Cybium, 9:107-119.

Received December 2004 Accepted March 2005 